\title{
Uso da técnica de Southern Blot/Hibridização associada à reaçáo em cadeia da polimerase para aumentar a sensibilidade no diagnóstico das infecçóes por hemoplasmas em gatos domésticos
}

\author{
Use of Southern Blot/Hybridization technique associated to polymerase chain reaction to improve \\ the sensitivity in the diagnosis of hemoplasma infections in domestic cats \\ Daniel B. Macieira* ${ }^{1 *}$ Rita de Cássia A. A. de Menezes² $^{2}$ Cristiane B. Damico ${ }^{3}$; \\ Nádia R. P. Almosny ${ }^{1}$; Joanne B. Messick ${ }^{4}$ \\ ${ }^{1}$ Departamento de Patologia e Clínica Veterinária, Faculdade de Veterinária, Universidade Federal Fluminense - UFF \\ ${ }^{2}$ Departamento de Parasitologia Animal, Instituto de Veterinária, Universidade Federal Rural do Rio de Janeiro - UFRRJ \\ ${ }^{3}$ Clínica Veterinária Gatos \& Gatos \\ ${ }^{4}$ Department Comparative Pathobiology, School of Veterinary Medicine, Purdue University
}

Recebido em 11 de Setembro de 2008

Aceito em 4 de Setembro de 2009

\section{Resumo}

O objetivo deste trabalho foi verificar se a técnica de Southern Blot/Hibridização $(\mathrm{SB})$ em associação à reação de polimerização em cadeia (PCR) aumenta a sensibilidade na detecçáo de DNA de hemoplasmas em gatos domésticos (Felis catus). O sangue total foi coletado em tubos contendo o anticoagulante ácido etilenodiamino tetra-acético, o DNA extraído a partir de 149 animais e a PCR realizada com o uso de sequências iniciadoras espécie-específicas, para amplificar subunidade $16 \mathrm{~S}$ do RNA ribossomal de Mycoplasma haemofelis e 'Candidatus M. haemominutum' dessas amostras. Para a hibridização, foram utilizadas sondas específicas quimicamente marcadas, e os resultados visualizados por meio da adição de substrato quimiluminescente seguida de autoradiografia. Dezoito (12,1\%) das 149 amostras testadas apresentaram resultado PCR-positivo para o DNA de hemoplasmas. A técnica de SB mostrou que 24/149 (16,1\%) amostras apresentaram resultado positivo para hemoplasmas, confirmando os 18 resultados PCR-positivos, além de revelar seis outros adicionais $(\mathrm{p}<0,001)$. O método de SB com sondas específicas mostrou-se mais sensível do que a PCR realizada isoladamente, sendo complementar para o diagnóstico das infecçóes causadas pelos hemoplasmas felinos.

Palavras-chave: Diagnóstico molecular, Felis catus, Mycoplasma spp.

\begin{abstract}
The aim of this study was to determine whether Southern Blot/Hybridization (SB) associated to Polymerase Chain Reaction (PCR) improves the sensitivity in the detection of hemoplasma DNA in domestic cats (Felis catus). Whole blood was collected in tubes containing the anticoagulant ethylenediamine tetra-acetic acid and DNA extracted from 149 animals. PCR was performed using species specific primers to amplify the 16S ribosomal RNA subunit of Mycoplasma haemofelis and 'Candidatus M. haemominutum' from these samples. Hybridization was performed using a $16 \mathrm{~S}$ rDNA probes chemically labeled and the results were visualized using a chemiluminescent substrate addition followed by autoradiography. Eighteen (12.1\%) of the 149 tested samples had a positive PCR result for hemoplasma species DNA. SB/hybridization technique showed that 24/149 (16.1\%) samples were positive for hemoplasmas, confirming the 18 PCR-positive results and reveling six additional positive animals $(\mathrm{p}<0.001)$. SB/hybridization method with specific probes was more sensitive than PCR performed alone, being complimentary to this technique to diagnose infections caused by feline hemoplasmas.
\end{abstract}

Keywords: Molecular diagnosis, Felis catus, Mycoplasma spp.

\footnotetext{
*Autor para correspondência: Daniel B. Macieira

Departamento de Patologia e Clínica Veterinária, Faculdade de Veterinária,

Universidade Federal Fluminense - UFF

Rua Vital Brasil Filho, 64, Santa Rosa, CEP 24230-340 Niterói - RJ, Brasil

e-mail: macieiradb@vm.uff.br (DBM); mcvalny@vm.uff.br (NRPA)

Apoio: CAPES e FAPERJ
} 


\section{Introdução}

Os hemoplasmas felinos eram conhecidos como isolados distintos (Ohio e California) de Haemobartonella felis, porém, após análises moleculares do gene 16S do RNA ribossomal (16S rRNA), foram alocados na classe Mollicutes e ordem Mycoplasmatales, sendo renomeados para o gênero Mycoplasma, espécies $M$. haemofelis e 'Candidatus M. haemominutum', respectivamente (FOLEY; PEDERSEN, 2001; NEIMARK et al., 2001). Os hemoplasmas são parasitos simples, com um genoma reduzido e que replicam por fissão binária. Até os dias de hoje, esses organismos não foram cultivados fora de seus hospedeiros definitivos (HARVEY, 2006).

A infecção por meio de artrópodes hematófagos é considerada o principal modo de transmissão dos hemoplasmas felinos, sendo a presença de Ctenocephalides felis frequentemente associada à de hemoplasmas (NASH; BOBADE, 1986; HACKETT et al., 2006; HARVEY, 2006). Há suspeitas de que carrapatos também possam estar envolvidos na transmissão desses parasitos, visto que o DNA de hemoplasmas foi identificado no gênero Ixodes e na espécie Rhipicephalus sanguineus (TAROURA et al., 2005; WILLI et al., 2007a).

No Brasil, os hemoplasmas felinos já foram identificados, molecularmente, em amostras de gatos domésticos dos Estados do Paraná, Rio de Janeiro e Rio Grande do Sul (MORAIS et al., 2007; MACIEIRA et al., 2008; SANTOS et al., 2009). Esse grupo de parasitos também foi identificado em felídeos selvagens mantidos em cativeiro nas cidades de Curitiba e de São Paulo, (GUIMARÃES et al., 2007a; WILLI et al., 2007b).

Uma terceira espécie de hemoplasma felino, 'Candidatus $\mathrm{M}$. turicensis', foi identificada na Suíça, Reino Unido, África do Sul, Austrália e Estados Unidos da América (EUA) (WILLI et al., 2005; WILLI et al. 2006; SYKES et al., 2008). No Brasil, até o momento, esse parasito foi descrito em felídeos selvagens mantidos em um zoológico da cidade de São Paulo e, em gatos domésticos, da região Sul do país (WILLI et al., 2007b; SANTOS et al., 2009).

Diversos são os métodos para o diagnóstico das infecções por hemoplasmas (HARVEY, 2006). No Brasil, o método mais utilizado é a avaliação de esfregaços de sangue periférico corados por técnicas de Romanovsky. Entretanto esse método é sabidamente pouco sensível e específico. Dessa forma, o uso de técnicas moleculares, como a reação em cadeia da polimerase (PCR), mais sensíveis e específicas que a citada anteriormente, é de grande importância no diagnóstico das infecçóes por hemoplasmas e estudos epidemiológicos (MESSICK et al., 1998). Recentemente, outra técnica, a PCR em tempo real, foi validada para a detecção de DNA de hemoplasmas felinos (TASKER et al., 2003), apresentando diversas vantagens em relação à PCR convencional. É bem mais rápida, altamente específica devido ao uso de um terceiro nucleotídeo (uma sonda marcada com reagente fluorescente) e permite a quantificação do DNA do hemoplasma em questão no sangue que, além de facilitar o entendimento do processo infecção-doença, pode ser útil na avaliação da resposta perante o tratamento (TASKER et al., 2003; BRADDOCK; TASKER; MALIK, 2004; WILLI et al. 2007c). Também se constitui em uma vantagem o fato desses ensaios serem realizados em sistemas de tubos fechados do início ao fim, o que reduz o risco de contaminaçáo e de resultados falso-positivos, (WILLI et al., 2007c). Entretanto, Sykes et al. (2007) encontraram uma sensibilidade similar entre as técnicas de PCR convencional e em tempo real.

A detecçáo de sequências específicas entre fragmentos de DNA, separados pela eletroforese em gel de agarose, foi descrita por Southern (1975), sendo o uso da técnica como ferramenta de diagnóstico respaldado na literatura científica (HARVEY; SOUNDY, 2005). Dessa forma, a PCR pode ter sua sensibilidade aumentada, se realizada em conjunto com técnica de Southern Blot/Hibridização (SB) do DNA amplificado (GUIMARÁES et al., 2007b; MACIEIRA et al., 2008).

Assim, o objetivo deste trabalho foi verificar se a técnica de SB em associação à PCR aumenta, de fato, a sensibilidade na detecção de DNA de hemoplasmas em gatos domésticos (Felis catus).

\section{Material e Métodos}

\section{Animais utilizados}

No período de fevereiro de 2005 a fevereiro de 2006, foram, prospectivamente, coletadas amostras sanguíneas, em tubos contendo o anticoagulante ácido etilenodiamino tetra-acético (EDTA), de 149 gatos domésticos, atendidos em uma clínica exclusiva para felinos $^{[1]}$, na cidade do Rio de Janeiro, Brasil. Essas amostras englobaram todos os animais testados para exposição/infecção aos retrovírus felinos FIV e FeLV, para a realização de um outro estudo acerca da prevalência de infecçóes por hemoplasmas nestes animais (MACIEIRA et al., 2008). Todos os procedimentos realizados contaram com autorização por escrito dos proprietários.

\section{Avaliação microscópica}

Esfregaços sangüíneos de sangue periférico foram confeccionados logo após a coleta. Os mesmos foram corados por técnica rápida ${ }^{[2]}$ de Romanovski. Apenas esfregaços com estruturas características dos parasitos, que não gerassem dúvidas aos profissionais envolvidos na avaliação, foram considerados positivos. Lâminas com estruturas similares aos microrganismos foram assinaladas como suspeitas, enquanto aquelas sem achados foram consideradas, apenas para efeito de classificação, negativas.

\section{Extração/purificação do DNA genômico}

O DNA total de cada amostra de sangue foi extraído e purificado no prazo de no máximo uma semana após a coleta. Esse procedimento foi realizado com uso de um kit comercial ${ }^{[3]}$ de acordo com as instruçôes do fabricante. As amostras de DNA foram mantidas a $-20{ }^{\circ} \mathrm{C}$ até a realização da PCR.

\footnotetext{
Clínica Veterinária Gatos \& Gatos, Rio de Janeiro, RJ.

${ }^{2}$ Panótico Rápido InstantProv, Newprov produtos para laboratório, Pinhais, PR.

${ }^{3}$ Generation Capture Column, Gentra Systems, Minneapolis, MN, EUA.
} 


\section{4. $P C R$}

As células sanguíneas podem apresentar componentes inibidores que levam a um resultado falso-negativo na PCR (AL-SOUD; RADSTRÖM, 2001). Dessa forma, o gene codificador da enzima gliceraldeído-3-fosfato desidrogenase (GAPDH) foi usado como verificador da presença de DNA amplificável na amostra, uma vez que é encontrado em todos os mamíferos, resultando na formação de um produto de 399 pares de base (pb) (BIRKENHEUER; LEVY; BREITSCHWERDT, 2003). As condiçóes de reação ${ }^{[4]}$ consistiram em uma etapa inicial de desnaturação a $94^{\circ} \mathrm{C}$, por 5 minutos, seguida de 30 ciclos de $95^{\circ} \mathrm{C}$ por 45 segundos; $55^{\circ} \mathrm{C}$ por 45 segundos; e $72{ }^{\circ} \mathrm{C}$ por 45 segundos, finalizando com uma extensão adicional de 2 minutos a $72{ }^{\circ} \mathrm{C}$. Foram utilizados os seguintes reagentes em suas concentraçóes finais: $1 \mathrm{X}$ Green GoTaq Flexi Buffer ${ }^{[5]}, 1,5 \mathrm{mM} \mathrm{MgCl}_{2}{ }^{[5]}, 0,2 \mathrm{mM}$ de cada dNTP ${ }^{[5]}$, $0,2 \mathrm{mM}$ de cada sequência iniciadora ${ }^{[6]}$ (Forward GAPDH-F 5'-CCTTCATTGACCTCAACTACAT-3' e Reverse GAPDH-R 5'-CCAAAGTTGTCATGGATGACC-3'), 1,25 U Go'Taq DNA Polimerase ${ }^{[5]}$, e água estéril q.s.p. $25 \mu \mathrm{L}^{[6]}$.

Todas as amostras, cuja presença de DNA amplificável foi verificada, através da PCR previamente descrita, foram testadas para a presença do gene $16 \mathrm{~S}$ rRNA de $M$. haemofelis e 'Candidatus M. haemominutum'.

Para se amplificar um fragmento parcial de $393 \mathrm{pb}$ do gene $16 \mathrm{~S}$ rRNA de $M$. haemofelis, a PCR foi executada com $5 \mu \mathrm{L}$ de DNA extraído em solução para um volume total de $25 \mu \mathrm{L}$ por reação. As concentraçóes finais dos reagentes da PCR foram: $50 \mathrm{mM} \mathrm{KCl}^{[5]}$, $10 \mathrm{mM}$ Tris- $\mathrm{HCl}^{[5]}, 0,1 \%$ Triton X-100 $0^{[5]}, 2,5 \mathrm{mM} \mathrm{MgCl}_{2}^{[5]}, 0,2 \mathrm{mM}$ de cada dNTP ${ }^{[5]}, 0,2$ mM de cada sequência iniciadora ${ }^{[6]}$ (Forward Hfelis-F1 5'-GACTTTGGTTTCGGCCAAGG-3' e Reverse Hfelis-R3 5'-CGAAGTACTATCATAATTATCCCTC-3'), 1 U de Taq DNA polimerase ${ }^{[5]}$, e água estéril para biologia molecular q.s.p. $25 \mu \mathrm{L}^{[6]}$. As condiçóes de reação consistiram de uma etapa inicial de desnaturação por 10 minutos a $94^{\circ} \mathrm{C}$, seguida de 43 ciclos de $94^{\circ} \mathrm{C}$ por 45 segundos, $54^{\circ} \mathrm{C}$ por 45 segundos, $72{ }^{\circ} \mathrm{C}$ por um minuto e um passo final de extensão a $72{ }^{\circ} \mathrm{C}$ por 7 minutos (BERENT; MESSICK; COOPER, 1998).

A PCR para a detecção do DNA de Candidatus M. haemominutum', foi realizada de acordo com Foley et al. (1998), com o mesmo volume de DNA em solução, assim como as mesmas concentraçóes dos reagentes descritos para a identificação do DNA de $M$. haemofelis, sendo utilizadas as sequências iniciadoras Forward Cali-F1 (5'-GCATAATGTGTCGCAATC-3') e Reverse Cali-R1 (5'-GTTTCAACTAGTACTTTCTCCC-3'). Os reagentes utilizados foram dos mesmos fabricantes que os da reação previamente descrita. As condiçôes de reação utilizadas consistiram em uma etapa inicial de desnaturação de 4 minutos a $94{ }^{\circ} \mathrm{C}$, seguida de 35 ciclos de $94^{\circ} \mathrm{C}$ por 30 segundos, $53{ }^{\circ} \mathrm{C}$ por 1 minuto e $70{ }^{\circ} \mathrm{C}$ por 45 segundos, encerrando-se com uma

\footnotetext{
${ }^{4}$ Informação pessoal fornecida via correio eletrônico pelo Dr. A. J. Birkenheuer. Department of Clinical Sciences, College of Veterinary Medicine, North Carolina State University, Raleigh, Carolina do Norte, EUA.

${ }^{5}$ Promega, Madison, WI, EUA.

${ }^{6}$ Integrated DNA Technologies - IDT - Coralville, IA, EUA.
}

etapa adicional de extensão por 5 minutos a $70{ }^{\circ} \mathrm{C}$, resultando, assim, em um produto de $191 \mathrm{pb}$.

Controles positivos e negativos, pertencentes ao grupo deste trabalho, foram utilizados no presente estudo. Esses controles consistiram de amostras sabidamente positivas e negativas para a presença de GAPDH e também para DNA dos hemoplasmas testados.

Os produtos amplificados foram analisados por meio de eletroforese em gel de agarose $\mathrm{e}^{[7]}$ a $1,5 \%$, em solução tampão Tris-acetato-EDTA ( $40 \mathrm{mM}$ Tris-Acetato e $1 \mathrm{mM}$ EDTA), contendo $0,5 \mathrm{mg} \cdot \mathrm{mL}^{-1}$ de brometo de etídeo ${ }^{[7]}$. Os resultados foram visualizados e documentados sob transluminador ultravioleta ${ }^{[8]}$. Para a determinação do tamanho dos produtos amplificados, foi utilizado o marcador de peso molecular de $100 \mathrm{pb}^{[7]}$. As fotografias obtidas digitalmente foram posteriormente ajustadas em programa para tratamento de imagens ${ }^{[9]}$ para melhor visualização e acabamento.

\section{Southern Blot e hibridização}

A transferência dos produtos da PCR (Southern Blot) foi realizada em todas as amostras testadas após eletroforese e visualização/documentação do gel. Usando-se um sistema rápido de transferência ${ }^{[10]}$, os géis de PCR foram submetidos à desnaturação alcalina ( $3 \mathrm{M} \mathrm{NaCl}, 0,4 \mathrm{M} \mathrm{NaOH}$ ) e neutralização (1 M tampão fosfato, $\mathrm{pH}$ 6,8), e transferidos para uma membrana de náilon positivamente carregada ${ }^{[11]}$, conforme descrito por Chomczynski (1992) e de acordo com as instruçôes do fabricante.

As reações de hibridização foram conduzidas pelo método quimiluminescente, não-radioativo, para a detecção de ácidos nucleicos (HÖLTKE et al., 1992). Sondas específicas para o DNA de $M$. haemofelis e 'Candidatus M. haemominutum' foram sintetizadas com a substituição dos dNTPs utilizados na PCR convencional pelo 'PCR DIG Labeling mix' ${ }^{[12]}$, resultando em sequências quimicamente marcadas de 393 pb e 191 pb para ambos os hemoplasmas, respectivamente, de acordo com as instruçóes dos fabricantes. Uma vez contendo os produtos transferidos do gel, as membranas foram pré-hibridizadas por duas horas a $45^{\circ} \mathrm{C}$, usando-se a solução 'DIG Easy Hyb ${ }^{\text {'[12] }}$, seguida por hibridização durante a noite ou por 12 horas a $45^{\circ} \mathrm{C}$ com as sondas específicas. Após essa etapa, a membrana de náilon foi bloqueada, incubada com anticorpos quimiluminescentes e radiografadas. Todos os passos previamente descritos foram realizados por intermédio de reagentes contidos em kit comercial ${ }^{[12]}$. As radiografias foram digitalizadas e colocadas em conjunto com seus géis correspondentes com o uso de programa para tratamento de imagens ${ }^{[9]}$.

\footnotetext{
Invitrogen, Carlsbad, CA, EUA.

${ }^{8}$ Kodak Gel Logic 100 Imagins System, Eastman Kodak Corporation, Rochester, NY, EUA

${ }^{9}$ Adobe Photoshop CS2, Adobe Systems Incorporated, San Jose, EUA.

${ }^{10}$ TurboblotterTM Rapid Downward Transfer Systems (Whatman ${ }^{\circledR}$ Schleicher \& Schuell, Keene, NH)

${ }^{11}$ Nytran ${ }^{\circledR}$ SuPerCharge TurboBlotterTM (Whatman ${ }^{\circledR}$ Schleicher \& Schuell, Keene, NH, EUA)

${ }^{12}$ DIG-Systems for non-reactive nucleic acid labeling and detection, Roche Diagnostic Corporation, Indianapolis, IN, EUA
} 


\section{Análise estatística}

Estimativas de ocorrência e intervalos de confiança (IC) a 95\% exatos, obtidos por meio de teste de probabilidade binomial, foram calculados para cada desfecho nos animais testados para a presença dos hemoplasmas (positivos e negativos). Comparaçóes entre os diferentes testes foram realizadas por meio dos testes não-paramétricos de Qui-quadrado $\left(\chi^{2}\right)$ ou exato de Fisher, quando

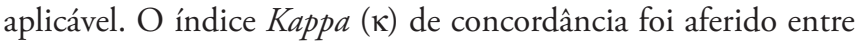
as técnicas de PCR realizada de forma isolada e em conjunto com a técnica de SB. Valores de $\mathrm{p}<0,05$ foram considerados estatisticamente significativos. A análise estatística foi realizada por meio dos programas "The Statistical Package for the Social Sciences for Windows v. 15.0" (SPSS, 2006) e "Stata v. 10.0" (STATACORP LP, 2007).

\section{Resultados e Discussáo}

Todas as 149 amostras testadas para a presença de hemoplasmas possuíam DNA amplificável, conforme comprovado pela amplificação de parte do gene GAPDH dessas amostras (Figura 1), sendo, portanto, incluídas no estudo.

Dos 149 animais testados, no presente trabalho, apenas um $(0,67 \%$; IC-95 $0-3,7 \%)$ teve um resultado certamente positivo pela análise do esfregaço sanguíneo, enquanto 18 (12,1\%; IC 95\% 7,3 - 18,4\%) amostras analisadas apresentaram resultado positivo para o DNA de pelo menos um hemoplasma. Uma vez que não era objetivo a identificaçáo de espécies, e sim verificar o aumento da sensibilidade do diagnóstico, resultados positivos para a presença de DNA de $M$. haemofelis e 'Candidatus M. haemominutum' foram tratados de forma genérica como positivos para hemoplasmas. A PCR confirmou a amostra previamente identificada pela avaliação do esfregaço sanguíneo e revelou ainda 17 novos animais infectados. Dessa forma, a PCR mostrou ser uma técnica muito mais sensível do que a microscopia ótica para diagnosticar infecçóes por hemoplasmas ( $<<0,001)$. Ressalta-se que, durante a realização deste trabalho, não havia técnica padronizada para a detecção de 'Candidatus M. turicensis' por meio de PCR convencional, sendo essa técnica descrita recentemente (SANTOS et al., 2009).

O método mais comum para a identificação de $M$. haemofelis é a visualização do parasito no esfregaço sanguíneo, corado por alguma técnica de Romanowsky, e as desvantagens do uso desse método para se estabelecer o diagnóstico de infecçóes por hemoplasmas são bem documentadas (TASKER; LAPPIN, 2002). Devido à natureza cíclica das parasitemias, a ausência de microrganismos em esfregaços sanguíneos não exclui um diagnóstico de infecção por hemoplasma. Outras causas de resultados falso-negativos incluem a falha na observação do parasito durante a avaliação do esfregaço sanguíneo e, ainda, um excesso de exposição do sangue ao EDTA após a coleta. (HARVEY; GASKIN, 1977; ALLEMAN et al., 1999; MESSICK, 2003; HARVEY, 2006). Uma crenação excessiva das hemácias de felinos pode acontecer, se os esfregaços forem preparados após algum tempo da coleta do sangue ou ainda se a secagem ocorrer de forma muito lenta, podendo obscurecer a presença de parasitos (BUTT, 1990). 'Candidatus M. haemominutum' é

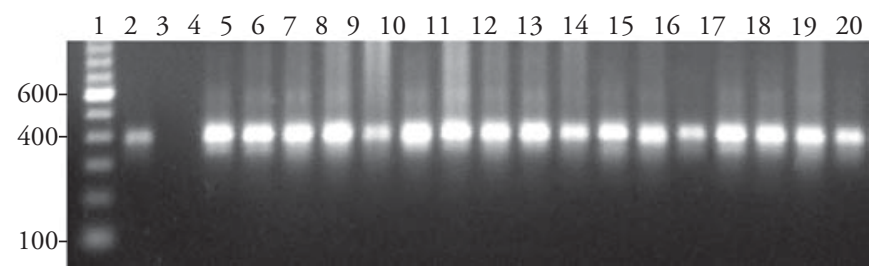

Figura 1. Resultado ilustrativo da PCR para a detecção de um produto de 399 pares de base ( $\mathrm{pb}$ ) de uma porção do gene GAPDH, para comprovação da presença de DNA amplificável nas 149 amostras de sangue coletadas de gatos domésticos. (1): Marcador de peso molecular $100 \mathrm{pb}$; (2): Controle positivo de DNA amplificável GAPDH; (3): Controle negativo - água; (4 a 20): amostras em estudo, todas positivas para a presença do gene em questão.

raramente visualizado no sangue, e, quando presente, é de difícil identificação, visto seu tamanho bem reduzido e similaridade com artefatos. Dessa forma, a identificação molecular é o único método confiável para a diferenciação das espécies desse grupo de parasitos de eritrócitos de felinos (MESSICK et al., 1998; FOLEY et al. 1998; INOKUMA et al., 2004; TASKER; LAPPIN, 2006). Essa mesma dificuldade ocorre para a identificação microscópica de 'Candidatus M. turicensis', somente possível por meio de técnicas moleculares (WILLI et al., 2007c). Esses fatores, provavelmente, levaram ao pequeno número de resultados positivos (apenas um) para hemoplasmas, no presente estudo, quando avaliados somente esfregaços sanguíneos.

Além de uma elevada concordância com a PCR $(\kappa=0,834)$ e a confirmação de todos os resultados positivos nela obtidos (Figura 2), a técnica de SB revelou seis resultados positivos adicionais para a presença de DNA de hemoplasmas (Figura 3), totalizando 24/149 (16,1\%; IC 95\% 10,6 - 23,0\%) amostras positivas ( $\mathrm{p}<0,001)$. $\mathrm{O}$ aumento de sensibilidade obtido com o uso da técnica de SB/hibridização corrobora diversos autores (NASRALLA et al., 1999; SANDER; PENNO, 1999; TAKAHASHI-OMOE et al., 2004; GUIMARÁES et al., 2007b). No presente estudo, foi utilizado um método rápido de transferência dos produtos da PCR em gel de agarose para membranas de náilon positivamente carregadas, que resultou em sinais mais intensos e sensibilidade relativamente mais elevada na etapa seguinte de hibridização, porque retém o DNA quantitativamente (CHOMCZYNSKI, 1992; HÖLTKE et al., 1992). Esse método aumenta a sensibilidade e eficiência da transferência do DNA presente no gel, permitindo que essa transferência ocorra de forma completa e rápida, ao contrário de técnicas convencionais, em que essa etapa pode durar até 12 horas (CHOMCZYNSKI, 1992). Em complemento à transferência dos produtos para uma membrana (SB), foi adotado um sistema que utiliza a digoxina para a detecção de ácidos nucleicos (HÖLTKE et al., 1992). Esse método detecta a presença do DNA alvo por intermédio de quimiluminescência, possuindo, por isso, diversas vantagens em relação ao uso de marcadores radioativos: alta sensibilidade, ausência de background e fácil remarcação da membrana com sondas. Por ser um método náo-radioativo, apresenta uma maior estabilidade, menor risco à biossegurança, tanto no que se refere ao manuseio quanto ao descarte do material utilizado, sendo, assim, uma alternativa favorável em relação aos métodos radioativos. 


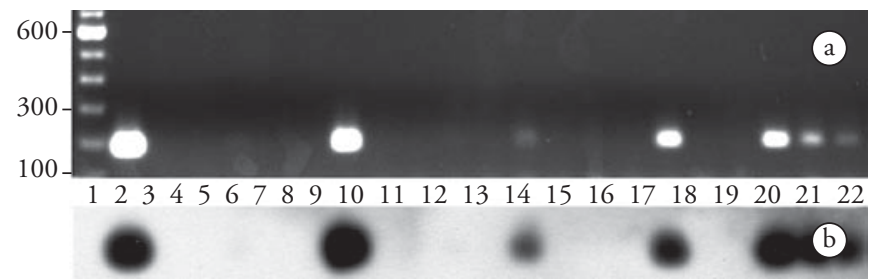

Figura 2. Resultados da PCR (A) (produto com 191 pares de base - $\mathrm{pb}$ ) e Southern Blot (B) para a detecção de uma porção do gene 16S rRNA de 'Candidatus Mycoplasma haemominutum' em gatos domésticos. (1): Marcador de peso molecular $100 \mathrm{pb}$; (2): Controle positivo de DNA; (3): Controle negativo - água; (4): Controle Negativo - DNA; (5 a 22): Amostras testadas para DNA de 'Candidatus M. haemominutum'.

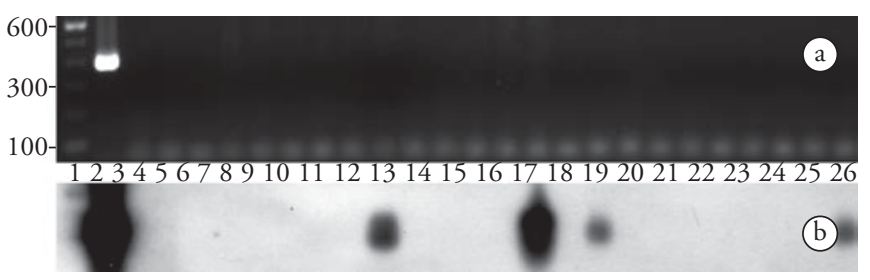

Figura 3. Resultados da PCR (A) (393 pares de base - pb) e Southern Blot (B) para a detecção de uma porção do gene $16 \mathrm{~S}$ rRNA de Mycoplasma haemofelis entre gatos domésticos. (1): Marcador de peso molecular 100 pb; (2): Controle positivo de DNA; (3): Controle negativo - água; (4): Controle Negativo - DNA; (5 a 26): Amostras testadas para DNA de $M$. haemofelis.

A sensibilidade da PCR, quando combinada com SB/hibridização, varia de $10 \mathrm{pg}$ a $100 \mathrm{fg}$ (TAKAHASHI-OMOE et al., 2004), e a hibridização do DNA mostrou-se 10 (SANDER; PENNO, 1999) a 100 (GUIMARÁES et al., 2007) vezes mais sensível do que a coloração de géis com brometo de etídeo, realizada de forma isolada para a detecção do DNA de bactérias e hemoplasmas, respectivamente. Apesar da presente pesquisa não ter definido limiares de sensibilidade das técnicas utilizadas, com base na literatura citada é possível concluir, por analogia, que o uso da técnica de Southern Blot/Hibridização em complemento à PCR eleva significativamente a sensibilidade do diagnóstico das infecções por hemoplasmas. Com base nos resultados deste trabalho e na literatura, tendo em vista que a PCR, em tempo real, para fins de diagnóstico ainda é pouco empregada no Brasil, em virtude do custo dos equipamentos, pode-se inferir que a técnica de SB/Hibridização de DNA associada à PCR é indicada para a obtenção de resultados mais fidedignos em estudos que envolvem o diagnóstico molecular de infecçóes por hemoplasmas e, possivelmente, outros agentes infecciosos.

\section{Agradecimentos}

À Clínica Veterinária Gatos \& Gatos e equipe, pelo apoio para a realização deste trabalho, bem como aos proprietários que autorizaram a inclusáo de seus animais no mesmo.

\section{Referências}

ALLEMAN, A. R. et al. Western immunoblot analysis of the antigens of Haemobartonella felis with sera from experimentally infected cats. Journal of Clinical Microbiology, v. 37, n. 5, p.1474-1479, 1999.

AL-SOUD, W. A.; RADSTROM, P. Purification and characterization of PCR-inhibitory components in blood cells. Journal of Clinical Microbiology, v. 39, n. 2, p. 485-493, 2001.

BERENT, L. M.; MESSICK, J. B.; COOPER, S. K. Detection of Haemobartonella felis in cats with experimentally induced acute and chronic infections, using a polymerase chain reaction assay. American Journal of Veterinary Research, v. 59, n. 10, p. 1215-1220, 1998.

BIRKENHEUER, A. J.; LEVY, M. G.; BREITSCHWERDT, E. B. Development and evaluation of a seminested PCR for detection and differentiation of Babesia gibsoni (Asian genotype) and B. canis DNA in canine blood samples. Journal of Clinical Microbiology, v. 41, n. 9, p. $4172-4177,2003$.

BRADDOCK, J. A.; TASKER, S.; MALIK, R. The use of real-time PCR in the diagnosis and monitoring of Mycoplasma haemofelis copy number in a naturally infected cat. Journal of Feline Medicine and Surgery, v. 6, n. 3, p. 161-165, 2004.

BUTT, M. T. Diagnosing erythrocyte parasitic diseases in cats. Compendium on Continuing Education for the Practicing Veterinarian, v. 12 , n. 5, p. 628-638, 1990.

CHOMCZYNSKI, P. One-hour downward alkaline capillary transfer for blotting of DNA and RNA. Analytical Biochemistry, v. 201, n. 1, p. 134-139, 1992.

FOLEY, J. E. et al. Molecular, clinical, and pathologic comparison of two distinct strains of Haemobartonella felis in domestic cats. American Journal of Veterinary Research, v. 59, n. 12, p. 1581-1588, 1998.

FOLEY, J. E.; PEDERSEN, N. C. “Candidatus Mycoplasma haemominutum", a low-virulence epierythrocytic parasite of cats. International Journal of Systematic and Evolutionary Microbiology, v. 51, n. 3, p. 815-817, 2001. (parte 3).

GUIMARÃES, A. M. et al. Molecular detection of "Candidatus Mycoplasma haemominutum” in a lion (Panthera leo) from a Brazilian zoological garden. Revista do Instituto de Medicina Tropical de São Paulo, v. 49, n. 3, p. 195-196, 2007a.

GUIMARÁES, A. M. et al. Exploratory study of Mycoplasma suis (Eperythrozoon suis) on four commercial pig farms in southern Brazil. The Veterinary Record, v. 160, n. 2, p. 50-53, $2007 \mathrm{~b}$.

HACKETT, T. B. et al. Prevalence of DNA of Mycoplasma haemofelis, “Candidatus Mycoplasma haemominutum”, Anaplasma phagocytophilum, and species of Bartonella, Neorickettsia, and Ehrlichia in cats used as blood donors in the United States. Journal of the American Veterinary Medical Association, v. 229, n. 5, p. 700-705, 2006.

HARVEY, B.; SOUNDY, P. Medical biomethods handbook. Totowa: Humana Press Inc., 2005. p. 35-42.

HARVEY, J. W. Hemotrophic mycoplasmosis (hemobartonelosis). In: GREENE, C. E. (Ed.). Infectious diseases of the dog and cat. 3 ed. Saint Louis: Elsevier Inc, 2006, p. 252-260.

HARVEY, J. W.; GASKIN, J. M. Experimental feline haemobartonellosis. Journal of the American Animal Hospital Association, v. 13, n. 1, p. 28-38, 1977. 
HÖLTKE, H. J. et al. Sensitive chemiluminescent detection of digoxigenin-labeled nucleic acids: a fast and simple protocol and its applications. Biotechniques, v. 12, n. 1, p. 104-113, 1992.

INOKUMA, H. et al. Molecular survey of Mycoplasma haemofelis and "Candidatus Mycoplasma haemominutum" infection in cats in Yamaguchi and surrounding areas. The Journal of Veterinary Medical Science, v. 66, n. 8, p. 1017-1020, 2004.

MACIEIRA, D. B. et al. Prevalence and risk factors for hemoplasmas in domestic cats naturally infected with feline immunodeficiency virus and/or feline leukemia virus in Rio de Janeiro-Brazil. Journal of Feline Medicine and Surgery, v. 10, n. 2, p. 120-129, 2008.

MESSICK, J. B. New perspectives about Hemotrophic mycoplasma (formerly, Haemobartonella and Eperythrozoon species) infections in dogs and cats. The Veterinary Clinics of North America Small Animal Practice, v. 33, n. 6, p. 1453-1465, 2003.

MESSICK, J. B.; BERENT, L. M.; COOPER, S. K. Development and evaluation of a PCR-based assay for detection of Haemobartonella felis in cats and differentiation of $H$. felis from related bacteria by restriction fragment length polymorphism analysis. Journal of Clinical Microbiology, v. 36, n. 2, p. 462-466, 1998.

MORAIS, H. A. et al. Co-infection with Mycoplasma haemofelis and 'Candidatus Mycoplasma haemominutum' in three cats from Brazil. Journal of Feline Medicine and Surgery, v. 9, n. 6, p. 518-520, 2007.

NASH, A. S.; BOBADE, P. A. Haemobartonella felis infection in cats from the Glasgow area. The Veterinary Record, v. 119, n. 15, p. 373-375, 1986.

NASRALLA, M.; HAIER, J.; NICOLSON. G. L. Multiple mycoplasmal infections detected in blood of patients with chronic fatigue syndrome and/ or fibromyalgia syndrome. European Journal of Clinical Microbiology and Infectious Diseases, v. 18, n. 12, p. 859-865, 1999.

NEIMARK, H. et al. Proposal to transfer some members of the genera Haemobartonella and Eperythrozoon to the genus Mycoplasma with descriptions of "Candidatus Mycoplasma Haemofelis", "Candidatus Mycoplasma haemomuris", "Candidatus Mycoplasma haemosuis" and "Candidatus Mycoplasma wenyonii". International Journal of Systematic and Evolutionary Microbiology, v. 51, n. 3, p. 891-899, 2001. (parte 3).

SANDER, A.; PENNO, S. Semiquantitative species-specific detection of Bartonella henselae and Bartonella quintana by PCR-enzyme immunoassay. Journal of Clinical Microbiology, v. 37, n. 10, p. 3097-3101, 1999.

SANTOS, A. P. et al. Design, optimization, and application of a conventional PCR assay with an internal control for detection of "Candidatus Mycoplasma turicensis" 16S rDNA in domestic cats from Brazil. Veterinary Clinical Pathology, 2009, doi: 10.1111/j.1939-16 5X.2009.00158.x.

SOUTHERN, E. M. Detection of specific sequences among DNA fragments separated by gel electrophoresis. Journal of Molecular Biology, v. 98, n. 3, p. 503-517, 1975.
STATISTICAL PACKAGE FOR SOCIAL SCIENCES - SPSS. Chicago: SPSS Inc., 2006.

STATACORP LP. Stata v. 10.0. College Station, TX: Copyright StataCorp LP, 2007.

SYKES, J. E et al. Detection of mixed infections with "Candidatus Mycoplasma haemominutum" and Mycoplasma haemofelis using real-time TaqMan polymerase chain reaction. Journal of Veterinary Diagnostic Investigation, v. 19, n. 3, p. 250-255, 2007.

SYKES J. E. et al. Prevalences of various hemoplasma species among cats in the United States with possible hemoplasmosis. Journal of the American Veterinary Medical Association, v. 232, n. 3. p. 372-379, 2008.

TAKAHASHI-OMOE, H. et al. Polymerase chain reaction with a primer pair in the 16S-23S rRNA spacer region for detection of Mycoplasma pulmonis in clinical isolates. Comparative Immunology, Microbiology and Infectious Diseases, v. 27, n. 2, p. 117-128, 2004.

TAROURA, S. et al. Detection of DNA of "Candidatus Mycoplasma Haemominutum" and Spiroplasma sp. in unfed ticks collected from vegetation in Japan. The Journal of Veterinary Medical Science, v. 67, n. 12, p. 1277-1279, 2005.

TASKER, S. et al. Use of real-time PCR to detect and quantify Mycoplasma haemofelis and "Candidatus Mycoplasma haemominutum” DNA. Journal of Clinical Microbiology, v. 41, n. 1, p. 439-441, 2003.

TASKER, S.; LAPPIN, M. R. Haemobartonella felis: recent developments in diagnosis and treatment. Journal of Feline Medicine and Surgery, v. 4, n. 1, p. 3-11, 2002.

TASKER, S.; LAPPIN, M. R. Update on hemoplasmosis. In: AUGUST, J. R. (Ed.). Consultations in feline internal medicine. 5 ed. Saint Louis: Elsevier Inc., 2006. p. 605-610.

WILLI, B. et al. Identification, molecular characterization, and experimental transmission of a new hemoplasma isolate from a cat with hemolytic anemia in Switzerland. Journal of Clinical Microbiology, v. 43, n. 6, p. 2581-2585, 2005.

WILLI, B. et al. Phylogenetic analysis of 'Candidatus Mycoplasma turicensis' isolates from pet cats in the United Kingdom, Australia, and South Africa, with analysis of risk factors for infection. Journal of Clinical Microbiology, v. 44, n. 12, p. 4430-4435, 2006.

WILLI, B et al. Real-time PCR investigation of potential vectors, reservoirs, and shedding patterns of feline hemotropic mycoplasmas. Applied and Environmental Microbiology, v. 73, n. 12, p.3798-3782, 2007a.

WILLI, B. et al. Worldwide occurrence of feline hemoplasma infections in wild felid species.Journal of Clinical Microbiology, v. 45, n. 4, p. 1159-1166, 2007b.

WILLI, B. et al. From Haemobartonella to hemoplasma: molecular methods provide new insights. Veterinary Microbiology, v. 125, n. $3 / 4$, p. $197-209,2007$ c. 